Economic and Environmental Geology

Research Paper

\title{
Analysis of Domestic Aggregate Production of Korea in 2019 (II) - by Local Governments
}

\author{
Sei Sun Hong, Jin Young Lee ${ }^{*}$ \\ Geologic Research Center, Korea Institute of Geoscience and Mineral Resources, 124 Gwahak-ro, Yuseong-gu, Daejeon 34132, Korea \\ *Corresponding author : jylee@kigam.re.kr

\section{ARTICLE INFORMATION} \\ Manuscript received 24 July 2021 \\ Received in revised form 20 August 2021 \\ Manuscript accepted 20 August 2021 \\ Available online 31 August 2021 \\ DOI : http://dx.doi.org/10.9719/EEG.2021.54.4.427

\section{Research Highlights} \\ - In 2019, a total of 148 local governments produced crushed stone, \\ sand and gravel. \\ - The leading producing local governments in 2019 were, in \\ descending order of volume, Ulju-gun, Hwasung-si, Cheongju-si, \\ Pocheon-si, Paju-si, Yongin-si, Gimhae-si. \\ - The combined production of the top 41 local governments was \\ about 93,000 thousand $\mathrm{m}^{3}$, which means that $28 \%$ the local \\ governments produced $70 \%$ of the total production in 2019 .
}

\begin{abstract}
On the base of the aggregate extraction statistics, this study tried to analyse the demand and supply of aggregate resources of each local government and provide directions for the stable and sustainable supply and demand of aggregate resources in the future. In 2019, aggregates were produced in 148 cities, about $65 \%$ of the 229 cities of Korea, but in 7 metropolitan cities with 74 local governments, only 19 cities developed the aggregate. It means that aggregate extraction is taking place in almost all regions in Korea. Sand and gravel were produced in 110 districts and 132 districts, respectively. By aggregate source, river aggregates were extracted in 4 local governments, land aggregates in 42 local governments, forest aggregates in 75 local governments, crushed aggregates in 105 local governments, and washing aggregates in 15 local governments. In other words, 81 district in Korea have not extracted land-based aggregate at all. 71 local governments produced only one type of aggregate, and 55 local governments developed two types of aggregate, and 22 local governments developed more than three types of aggregate. In 2019, the leading producing local governments were, in descending order of volume, Ulju-gun, followed by Hwaseong-si, Cheongju-si, Pocheon-si, Paju-si, Yongin-si, Gimhae-si, Gwangju-si in Gyeonggi-do. 41 local governments have developed aggregates of more than 1 million $\mathrm{m}^{3}$, and the combined production of the 41 cities accounted for about $70 \%$ of national total. This shows that the aggregate extraction trend of local governments is becoming larger and more concentrated.
\end{abstract}

Keywords : forest aggregate, screening crushed aggregate, land aggregate, sand, gravel

Citation: Hong, S.S., Lee, J.Y. (2021) Analysis of Domestic Aggregate Production of Korea in 2019 (II) - by Local Governments. Korea Economic and Environmental Geology, v.54, p.427-439, doi:10.9719/EEG2021.54.4.427.

This is an Open Access article distributed under the terms of the Creative Commons Attribution Non-Commercial License (http://creativecommons.org/ licenses/by-nc/3.0) which permits unrestricted non-commercial use, distribution, and reproduction in any medium, provided original work is properly cited. pISSN 1225-7281; eISSN 2288-7962/C2021 The KSEEG. Printed by Hanrimwon Publishing Company. All rights reserved. 


\title{
연구논문
}

\section{9년도 국내 골재 수급 분석 (II) - 시군구단위 분석 -}

\author{
홍세선 · 이진영* \\ 한국지질자원연구원 지질연구센터 \\ *책임저자 : jylee@kigam.re.kr
}

\section{요 약}

이번 연구에서는 골재채취통계를 기초로 하여 골재의 채취현황을 분석하고, 향후 골재의 안정적이고 지속적인 수급을 예측하 고자 하였다. 2019년에는 전국 229 개 시군구 중 약 $65 \%$ 인 148 개 시군구에서 한 종류 이상의 골재를 개발하였다. 7 대 광역시에 서는 19 개 시군구에서 골재를 개발되었다. 광역시를 제외하면 8 개도의 155 개 시군 중 $83 \%$ 인 129 개 시군에서 골재개발이 이루 어져 우리나라의 대부분 시군에서 골재를 개발하고 있다고 볼 수 있다. 모래는 110 개 시군구에서, 자갈은 132 개 시군구에서 개 발되었다. 골재원별로 볼 때 하천골재는 4 개 시군구, 육상골재는 42 개 시군구, 산림골재는 75 개 시군구, 선별파쇄골재는 105 개 시군구, 선별세척골재는 15 개 시군구에서 개발되었다. 또한 육지원 골재의 채취가 전혀 이루어지지 않은 시군구는 81 개 지역이 다. 골재원별로 볼 때 한 종류의 골재만 개발하는 시군구는 71 개, 두 종류의 골재를 개발하는 시군구는 55 개, 3 종류 이상은 22 개 시군구이다. 2019년에 골재의 개발이 가장 많은 지역은 울주군이며, 그 다음으로 화성시, 청주시, 포천시, 파주시, 용인시, 김 해시, 광주시의 순이다. 100 만m $\mathrm{m}^{3}$ 이상의 골재를 개발한 지역은 41 개 시군구로 시군구은 골재채취 시군구의 약 $28 \%$ 이지만 골재 개발량은 2019년도 총 개발량의 약 $70 \%$ 를 점유한다. 이는 각 시군의 골재채취가 대형화, 집중화되고 있음을 보여준다.

주요어 : 2019년 골재채취실적, 산림골재, 선별파쇄골재, 육상골재, 하천골재

\section{1. 서 론}

골재자원은 시멘트, 철근과 더불어 국가의 건설경제를 지탱하여 주는 3 대 필수 원자재이다. 도로, 철도, 항만, 공항 등의 사회기반시설과 국민의 주거환경에 이르기까 지 골재자원은 국민생활에 필수적으로 필요하며, 매우 중 요한 자원으로 인식되고 있다. 그러나 모래와 자갈로 대 변되는 골재자원은 우리 주변의 산이나 들에서 흔히 접 할 수 있어 무한한 자원으로 인식되어 왔으며, 손쉽게 얻 을 수 있다는 고정 관념에 사로 잡혀 안정적이고, 계획 적인 수요공급 측면을 고려한 연구는 많지 않은 편이다. 물의 경우에도 과거에는 산 계곡과 강에서 쉽게, 무료로 마실 수 있는 무한한 자원으로 인식되었지만 현재는 먹 는 물에 대한 연구과 기술개발에 막대한 노력을 기울이 고 있으며, 어느 누구도 먹는 물을 무료로 얻을 수 있다 고는 생각하지 않으며, 국가에서도 수자원의 보호에 매우 적극적인 정책을 펴고 있다. 골재자원은 의식주의 "주" 를 담당하는 자원으로 콘크리트를 사용하는 주거문화가 바뀌지 않는 이상 수자원 못지 않는 연구과 기술개발이 필요하다고 할 수 있다.

정부에서는 골재자원의 중요성을 인식하고 1991년에
골재채취법을 제정하였으며, 전국의 골재개발 현황을 매 년 국가통계로서 집계하고 있다. 이러한 통계자료는 골 재자원정보관리시스템(www.agris.go.kr)을 통해 대국민서 비스를 하고 있다. 골재자원의 수급현황에 대해서는 연 도별 전국단위 또는 광역적인 측면에서 분석된 바 있으 나(Hong et al., 2015; Hong and Lee, 2020; MLIT, 2014, 2018), 시군구 단위로 골재자원의 수급이 어떠한 형태로 보이는지에 대해서는 아직 연구된 바 없다. 따라서 이 연 구에서는 시군구의 골재채취 통계자료를 바탕으로 각 지 자체에서의 골재자원의 수요와 공급형태를 분석하고, 향 후 골재자원의 안정적인 수급에 대한 방향제시를 하고자 하였다.

\section{2. 연구방법}

일반적으로 골재의 수급통계는 권역별(시도 단위)로 집 계되고 있다. 집계방식은 기초자치단체의 골재담당부서 에서 골재의 채취현황을 파악하여, 광역자치단체의 해당 부서로 보고하고 광역자치단체에서는 이를 집계하여 정 부부처(국토교통부)의 담당부서에 보고하는 형태이다. 이 번 연구에는 2019년도의 각 시군별(기초자치단체) 골재 
채취통계를 바탕으로 하여 골재의 생산이 시군단위로 어 떠한 형태로 이루어지는가를 파악하였다.

분석대상 시군구는 서울, 인천, 대전, 대구, 울산, 부산, 광주의 7 개 광역시 내의 74 개 구와 군, 경기도 등 8 개 도 의 152 개 시군, 제주특별자치도의 2 개 시, 세종특별자치 시의 1 개 시 등 총 229 개 시군구이며, 이들을 대상으로 골재의 생산 형태 및 골재원들의 수급경향을 파악하고자 하였다. 골재의 통계는 먼저 허가와 신고의 두 형태로 구 분된다. 우리나라 골재의 분류는 골재채취법에 의해 채 취장소에 따른 분류를 택하고 있다. 따라서 허가에 의한 골재에 대해서는 하천골재, 육상골재, 산림골재, 바다골 재의 4 종류로 구분하며, 신고에 의한 골재는 하천골재 신고, 육상골재신고, 산림골재신고, 바다골재신고, 그리고 선별파쇄, 선별세척 등 6 종류로 분류한다. 그리고 분류 된 이들 골재의 하위에 모래와 자갈의 생산품목을 두고 있다. 2019년에는 약 1억3천4백만 $\mathrm{m}^{3}(\mathrm{EEZ}$ 물량 포함)의 골재가
채취되었으며, 골재종류별로 보면 하천골재 100 만 $\mathrm{m}^{3}(0.7 \%)$, 육상골재 440 만 $\mathrm{m}^{3}(3.3 \%)$, 산림골재 5,540 만 $\mathrm{m}^{3}(41.4 \%)$, 바다골재 230 만 $\mathrm{m}^{3}(1.7 \%)$, 선별파쇄 6,700 만 $\mathrm{m}^{3}(50.3 \%)$, 선별세척 230 만 $\mathrm{m}^{3}(1.7 \%)$, 기타신고골재 110 만 $\mathrm{m}^{3}(0.9 \%)$ 이다(Hong and Lee, 2020).

\section{3. 골재원별 분석}

\section{1. 하천골재}

2019년에는 조사대상 229개 시군구에서 단지 4개 시군 구에서만 하천골재를 개발하였다(Fig. 1(A) and Table 1). 하천골재를 개발한 시군구는 평창군, 의성군, 구미시, 의 령군이며, 이들 지역에서 생산된 하천골재의 총량은 100 만 $\mathrm{m}^{3}$ 이다. 구미시는 모래와 자갈을 모두 생산하였으며, 의령군과 의성군은 모래만, 평창군은 자갈만 생산하였다. 2004년도에 하천골재를 생산한 시군은 약 40 개 시군이었

Table 1. Rank of local governments produced aggregate in Korea, 2019

\begin{tabular}{|c|c|c|c|c|c|c|c|c|c|}
\hline & River & Land & Forest & Marine & Crushed & Washing & Sand & Gravel & $\begin{array}{c}\text { Production of } \\
\text { Aggregate }\end{array}$ \\
\hline 1 & Uiryong & Gochang & Ulju & Ongjin & Hwaseong & Changwon & Cheongju & Ulju & Ulju \\
\hline 2 & Gumi & $\begin{array}{c}\text { Goseong } \\
\text { (Gangwon) }\end{array}$ & Gimhae & EEZ Namhae & Pocheon & Seosan & Yongin & Hwaseong & Hwaseong \\
\hline 3 & Uiseong & Chungju & Wonju & & Yongin & $\begin{array}{l}\text { Saha-gu } \\
\text { (Busan) }\end{array}$ & Pocheon & Paju & Cheongju \\
\hline 4 & Pyeongchang & Uiseong & Yeonchoeng & & Gwangju & $\begin{array}{c}\text { Jung-gu } \\
\text { (Incheon) }\end{array}$ & Yeoju & Gwangju & Pocheon \\
\hline 5 & & Gimcheon & Paju & & Cheongju & $\begin{array}{l}\text { Nam-gu } \\
\text { (Ulsan) }\end{array}$ & Yangju & Wonju & Paju \\
\hline 6 & & Andong & Naju & & Namyangju & Jeju & Gimhae & $\begin{array}{c}\text { Seo-gu } \\
\text { (Incheon) }\end{array}$ & Yongin \\
\hline 7 & & Hampyeong & Cheongju & & Paju & Gimpo & Ongjin & Pocheon & Gimhae \\
\hline 8 & & Namwon & Chungju & & $\begin{array}{c}\text { Seo-gu } \\
\text { (Incheon) }\end{array}$ & Tongyeong & Hoengseong & Cheongju & $\begin{array}{c}\text { Gwangju } \\
\text { (Gyeonggi) }\end{array}$ \\
\hline 9 & & Yecheon & Anseong & & Yangju & $\begin{array}{c}\text { Seo-gu } \\
\text { (Incheon) }\end{array}$ & Namyangju & Gimhae & Anseong \\
\hline 10 & & Gangreung & Chuncheon & & Yeoju & Goheung & EEZ Namhae & Asan & Namyangju \\
\hline 11 & & Sangju & Jincheon & & Goyang & Sacheon & Paju & Chungju & Yeoncheon \\
\hline 12 & & Cheongju & Hongseong & & Asan & Boseong & Anseong & Naju & Wonju \\
\hline 13 & & Uljin & Hoengseong & & Sejong & Pyeongtaek & Hwaseong & Anseong & $\begin{array}{c}\text { Seo-gu } \\
\text { (Incheon) }\end{array}$ \\
\hline 14 & & Yeongju & Gunsan & & Uijeongbu & Gwangyang & Yeoncheon & Yeoncheon & Yangju \\
\hline 15 & & Gyeongju & Haenam & & Angseong & Geoje & Sejong & Namyangju & Asan \\
\hline 16 & & Donghae & Namwon & & Yesan & & Gwangju & Jincheon & Yeoju \\
\hline 17 & & Wonju & Haman & & Ulju & & Goyang & Sejong & Chungju \\
\hline 18 & & Sejong & Pocheon & & Yangsan & & Uijeongbu & Yangsan & Seojong \\
\hline 19 & & Gongju & Hwasun & & Gimpo & & Uiryong & Hongseong & Goyang \\
\hline 20 & & Hwasun & Jeongup & & Iksan & & Jincheon & Goyang & Jincheon \\
\hline
\end{tabular}



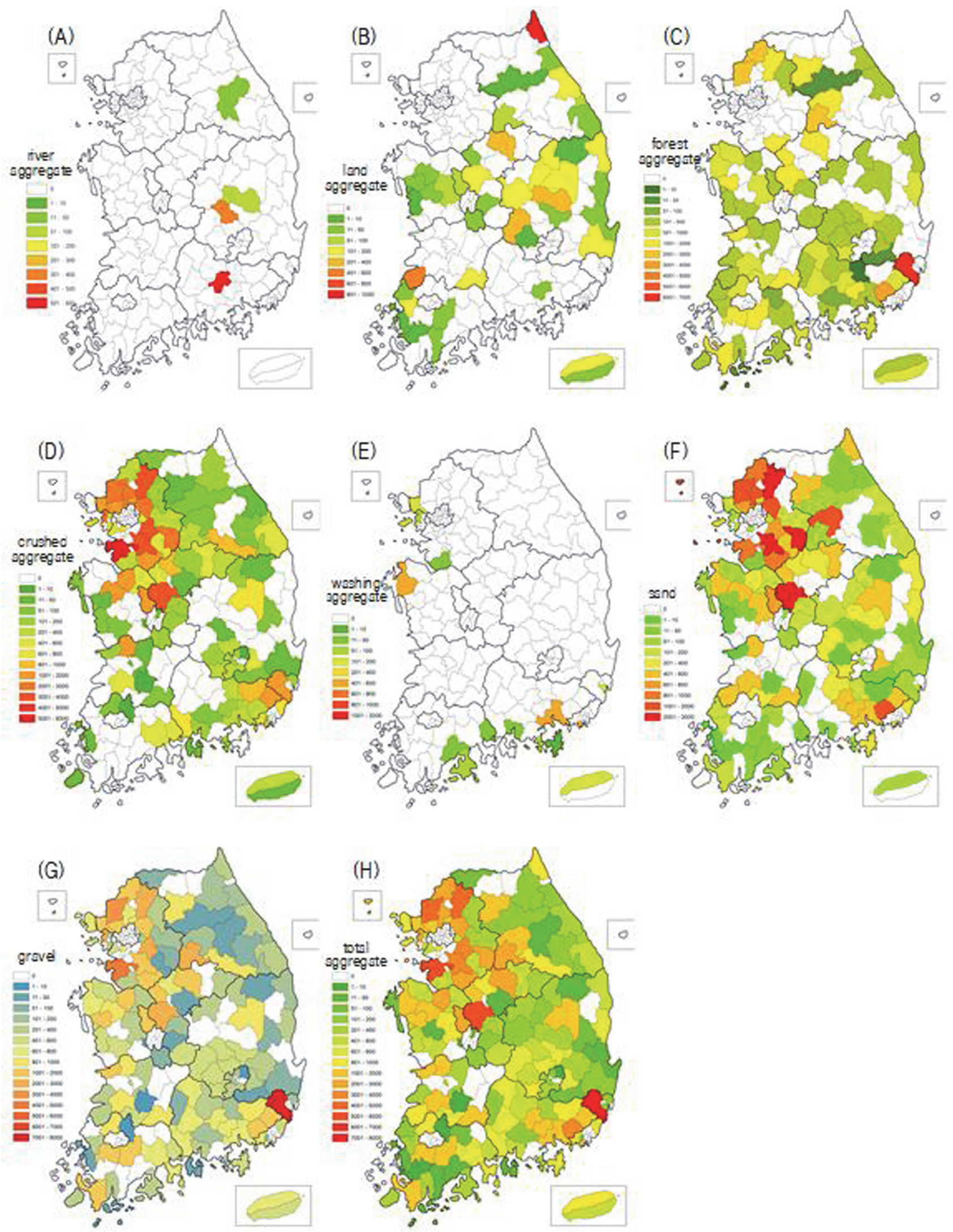

Fig. 1. The distribution map of domestic aggregate by local government. (unit : thousand $\mathrm{m}^{3}$ ) (A) river aggregate, (B) land aggregate, (C) forest aggregate, (D) crushed aggregate, (E) washing aggregate, (F) sand, $(\mathrm{G})$ gravel, $(\mathrm{H})$ total aggregate. 
으며, 100 만 $\mathrm{m}^{3}$ 이상을 생산한 시군도 10 개 지역이었다. 그러나 4 대강 사업 이후 하천골재의 생산량은 급감하기 시작하여 현재는 극히 일부 지역에서 소규모로 개발되고 있으며, 골재의 수급조절 기능은 많이 약화된 상황이다.

\section{2. 육상골재}

육상골재는 42 개 시군구에서 개발되었으며, 이는 전체 조사대상 229 개 시군구의 약 $18 \%$ 에 해당된다(Fig. 1(B)).
Table 1에서 보는 바와 같이 육상골재의 개발은 경상북 도가 13 개 시군구로 가장 많으며, 강원도, 전라남도가 각 각 7 개 시군구, 충청남도 6 개 시군구, 충청북도 4 개 시군 구, 전라북도와 제주도가 각각 2 개 시군구, 그리고 세종 특별자치시에서 이루어졌다. 100 만 $\mathrm{m}^{3}$ 이상의 육상골재 를 개발한 시군은 없으며, 강원도 고성군이 약 81 만 $\mathrm{m}^{3}$ 로 가장 많은 채취실적을 보인다(Fig. 1(B)). 육상골재 개 발은 주로 모래를 중심으로 이루어졌으며, 모래는 40 개

Table 2. The number of aggregate sources in Korea in 2019, by local government

\begin{tabular}{|c|c|c|c|c|c|c|c|c|c|c|c|c|}
\hline $\begin{array}{l}\text { No. of local } \\
\text { governments }\end{array}$ & $\begin{array}{c}\text { Total } \\
\text { Extraction }\end{array}$ & Permission & Declaration & Sand & Gravel & River & Land & Mountain & Marine & Crushed & Washing & Others \\
\hline Seoul(25) & 0 & 0 & 0 & 0 & 0 & 0 & 0 & 0 & 0 & 0 & 0 & 0 \\
\hline Incheon(10) & 6 & 1 & 5 & 5 & 5 & 0 & 0 & 0 & 1 & 4 & 2 & 0 \\
\hline Daejeon(5) & 1 & 0 & 1 & 1 & 0 & 0 & 0 & 0 & 0 & 1 & 0 & 0 \\
\hline Gwangju(5) & 0 & 0 & 0 & 0 & 0 & 0 & 0 & 0 & 0 & 0 & 0 & 0 \\
\hline Daegu(8) & 4 & 0 & 4 & 1 & 4 & 0 & 0 & 0 & 0 & 4 & 0 & 0 \\
\hline Busan(16) & 5 & 0 & 5 & 2 & 5 & 0 & 0 & 0 & 0 & 5 & 1 & 0 \\
\hline Ulsan(5) & 3 & 1 & 3 & 2 & 2 & 0 & 0 & 1 & 0 & 2 & 1 & 0 \\
\hline Sejong(1) & 1 & 1 & 1 & 1 & 1 & 0 & 1 & 1 & 0 & 1 & 0 & 0 \\
\hline Gyeonggi-do(31) & 20 & 5 & 20 & 18 & 20 & 0 & 0 & 5 & 0 & 20 & 2 & 0 \\
\hline Gangwon-do(18) & 15 & 10 & 12 & 11 & 15 & 1 & 7 & 6 & 0 & 12 & 0 & 1 \\
\hline Chungcheongnam-do(15) & 13 & 10 & 10 & 11 & 11 & 0 & 6 & 7 & 0 & 9 & 1 & 0 \\
\hline Chungcheongbuk-do(11) & 10 & 6 & 9 & 7 & 9 & 0 & 4 & 5 & 0 & 9 & 0 & 0 \\
\hline Jeollabuk-do(14) & 9 & 8 & 6 & 7 & 9 & 0 & 2 & 8 & 0 & 6 & 0 & 1 \\
\hline Jeollanam-do(22) & 20 & 16 & 10 & 12 & 14 & 0 & 6 & 13 & 0 & 7 & 3 & 1 \\
\hline Gyeongsangbuk-do(23) & 21 & 20 & 11 & 18 & 17 & 2 & 13 & 14 & 0 & 11 & 0 & 0 \\
\hline Gyeongsangnam-do(18) & 18 & 13 & 13 & 12 & 18 & 1 & 1 & 13 & 0 & 12 & 4 & 1 \\
\hline Jeju-do(2) & 2 & 2 & 2 & 1 & 2 & 0 & 2 & 2 & 0 & 2 & 1 & 0 \\
\hline 합계 & 148 & 93 & 112 & 109 & 132 & 4 & 42 & 75 & 1 & 105 & 15 & 4 \\
\hline
\end{tabular}

Table 3. The aggregate product in Korea in 2019, by aggregate sources

\begin{tabular}{|c|c|c|c|c|c|c|c|c|c|c|c|c|}
\hline \multirow{2}{*}{$\begin{array}{c}\text { Size range } \\
\left(\text { thousand } \mathrm{m}^{3} \text { ) }\right.\end{array}$} & \multicolumn{12}{|c|}{ number of local governments by aggregate sources } \\
\hline & $\begin{array}{c}\text { Total } \\
\text { Extraction }\end{array}$ & Permission & Declaration & Sand & Gravel & River & Land & Mountain & Marine & Crushed & Washing & Others \\
\hline$>500$ & 3 & 1 & 1 & 0 & 1 & 0 & 0 & 1 & 0 & 1 & 0 & 0 \\
\hline $400 \sim 500$ & 2 & 0 & 0 & 0 & 1 & 0 & 0 & 0 & 0 & 0 & 0 & 0 \\
\hline $300 \sim 400$ & 3 & 1 & 4 & 0 & 1 & 0 & 0 & 1 & 0 & 4 & 0 & 0 \\
\hline $200 \sim 300$ & 10 & 3 & 6 & 4 & 5 & 0 & 0 & 3 & 0 & 5 & 0 & 0 \\
\hline $100 \sim 200$ & 24 & 17 & 10 & 7 & 17 & 0 & 0 & 14 & $2 *$ & 10 & 0 & 0 \\
\hline $50 \sim 100$ & 34 & 19 & 17 & 18 & 32 & 1 & 2 & 16 & 0 & 16 & 1 & 1 \\
\hline $10 \sim 50$ & 50 & 35 & 41 & 42 & 53 & 1 & 14 & 34 & 0 & 38 & 6 & 2 \\
\hline $5 \sim 10$ & 6 & 3 & 14 & 13 & 8 & 1 & 4 & 2 & 0 & 13 & 3 & 1 \\
\hline $1 \sim 5$ & 12 & 11 & 14 & 18 & 11 & 1 & 16 & 3 & 0 & 14 & 4 & 2 \\
\hline$<1$ & 5 & 4 & 5 & 8 & 3 & 0 & 6 & 1 & 0 & 4 & 1 & 0 \\
\hline total & 144 & 90 & 107 & 102 & 129 & 4 & 36 & 74 & 2 & 101 & 14 & 6 \\
\hline
\end{tabular}


시군구에서, 자갈은 7 개 시군구에서 개발되었다. Table 3 에서 보는 바와 같이 10 만 50 만 $\mathrm{m}^{3}$ 를 채취한 시군구가 14 개이며, 5 10만 $\mathrm{m}^{3}$ 를 채취한 시군구는 4 개 시군구, 1 만 5 만 $\mathrm{m}^{3}$ 을 채취한 시군구는 16 개 시군구, 1 만 $\mathrm{m}^{3}$ 이하 는 6개 시군구이다. 육상골재 개발 상위 시군구(Table 2) 는 강원도 고성군 $\left(81\right.$ 만 $\left.\mathrm{m}^{3}\right)>$ 고창군 $\left(51\right.$ 만 $\left.\mathrm{m}^{3}\right)>$ 충주시(29만 $\left.\mathrm{m}^{3}\right)>$ 의성군 $\left(26\right.$ 만 $\left.\mathrm{m}^{3}\right)>$ 김천시 $\left(20\right.$ 만 $\left.\mathrm{m}^{3}\right)>$ 안동시 $\left(19\right.$ 만 $\left.\mathrm{m}^{3}\right)>$ 함평군 $\left(19\right.$ 만 $\mathrm{m}^{3}>$ 남원시 $\left(18\right.$ 만 $\left.\mathrm{m}^{3}\right)>$ 예천군 $\left(17\right.$ 만 $\mathrm{m}^{3}>$ 강릉시 $\left(16\right.$ 만 $\left.\mathrm{m}^{3}\right)$ 순이다.

\section{3. 산림골재}

산림골재는 75 개 시군구에서 개발되었으며, 전국 229 개 시군구의 $33 \%$ 에 해당된다(Fig. $1(\mathrm{C})$ ). 산림골재는 전국의 모든 도에서 개발되었으며, 경상북도가 14 개 시군구로 가 장 많으며, 경상남도와 전라남도가 각각 13 개 시군구, 전라 북도 8 개 시군구, 충청남도 7 개 시군구, 강원도 6 개 시군 구, 경기도와 충청북도가 각각 5 개 시군구, 제주특별자치도 2 개 시, 세종특별자치시와 울산광역시가 각각 1 개 시군이 다(Table 1). 산림골재에서는 모래보다는 자갈의 개발이 더 활발하여, 모래는 24 개 시군구에서, 자갈은 73 개 시군구 에서 개발하였다. Table 3 에서 보는 바와 같이 500 만 $\mathrm{m}^{3}$ 를 개발한 지역은 울산광역시 울주군의 1개 군이며, 300 400 만 $\mathrm{m}^{3}$ 를 개발한 지역은 1 개 시군구, 200 300만 $\mathrm{m}^{3}$ 를 개 발한 지역은 3 개 시군구, $100 ~ 200$ 만 $\mathrm{m}^{3}$ 를 개발한 지역은 14 개 시군구이다. 100 만 $\mathrm{m}^{3}$ 이상의 산림골재를 개발하는 시군구는 19 개 시군구로 산림골재 개발 시군구의 $25 \%$ 이 지만 골재개발량은 3,400 만 $\mathrm{m}^{3}$ 로 전국 산림골재 개발량 의 약 $62 \%$ 를 차지한다. $10 \sim 50$ 만 $\mathrm{m}^{3}$ 를 개발한 지역이 34 개 시군구로 가장 많지만 개발량은 약 1 천만 $\mathrm{m}^{3}$ 로 전국 산림골재 개발량의 약 $17 \%$ 를 차지한다. 산림골재 개발 상위 시군구(Table 2)는 울주군(670만 $\left.\mathrm{m}^{3}\right)>$ 김해시(301만 $\left.\mathrm{m}^{3}\right)>$ 원주시 $\left(215\right.$ 만 $\left.\mathrm{m}^{3}\right)>$ 연천군 $\left(213\right.$ 만 $\left.\mathrm{m}^{3}\right)>$ 파주시 $\left(206\right.$ 만 $\left.\mathrm{m}^{3}\right)>$ 나주시 $\left(181\right.$ 만 $\left.\mathrm{m}^{3}\right)>$ 청주시 $\left(175\right.$ 만 $\left.\mathrm{m}^{3}\right)>$ 충주시 $\left(167\right.$ 만 $\left.\mathrm{m}^{3}\right)>$ 안 성시와 춘천시 $\left(149\right.$ 만 $\left.\mathrm{m}^{3}\right)$ 순이다. 김해시, 횡성군에서는 산림모래를 100 만 $\mathrm{m}^{3}$ 이상을 개발하였으며, 산림자갈은 울주군, 원주시 등 13 개 시군구에서 개발하였다.

\section{4. 바다골재}

바다골재는 인천광역시 옹진군과 배타적경제수역(EEZ) 의 2 개소에서만 개발되었다Table 2). 바다골재에서는 모 두 모래만 개발되었으며 개발량도 약 132 만 $\mathrm{m}^{3}$ 로 매우 적은 편이다.

\section{5. 선별파쇄골재}

선별파쇄골재는 105 개 시군구에서 채취되었으며, 전국
229개 시군구의 약 46\%를 점유한다(Fig. 1(D)). 선별파쇄 골재는 서울과 대전을 제외한 전국의 모든 시도에서 채 취되었으며, 경기도가 20 개 시군구로 가장 많으며, 강원 도와 경상남도 각각 12 개 시군구, 경상북도 11 개 시군구, 충청남도와 충청북도 9 개 시군구, 전라남도 7 개 시군구, 전라북도 6 개 시군구, 부산광역시 5 개 구군, 인천광역시 와 대구광역시가 각각 4 개 시군구, 울산광역시와 제주특 별자치도가 각각 2 개 시군, 그리고 대전광역시와 세종특 별자치시가 각각 1 개 시군이다(Table 1). 선별파쇄골재에 서는 모래보다는 자갈의 개발이 더 활발하여, 모래는 62 개 시군구에서, 자갈은 93 개 시군구에서 개발하였다. Table 3에서 보는 바와 같이 500 만 $\mathrm{m}^{3}$ 를 개발한 지역은 경기도 화성군이며, $300 \sim 400$ 만 $\mathrm{m}^{3}$ 를 개발한 지역은 4 개 시군구, 200 300만 $m^{3}$ 를 개발한 지역은 5 개 시군구, 100 200 만 $\mathrm{m}^{3}$ 를 개발한 지역은 10 개 시군구이다. 100 만 $\mathrm{m}^{3}$ 이상 의 선별파쇄골재를 채취하는 시군구는 20 개 시군구로 선 별파쇄골재 채취 시군구의 $19 \%$ 이지만 골재개발량은 약 4,490 만 $\mathrm{m}^{3}$ 로 전국 선별파쇄골재 채취량의 약 $67 \%$ 를 차 지한다. $10 \sim 50$ 만 $\mathrm{m}^{3}$ 를 개발한 지역이 38 개 시군구로 가 장 많지만 개발량은 약 1,000 만 $\mathrm{m}^{3}$ 로 전국 선별파쇄골재 채취량의 약 $15 \%$ 를 차지한다. 선별파쇄골재 채취 상위 시군구(Table 2$)$ 는 화성군 $\left(571\right.$ 만 $\left.\mathrm{m}^{3}\right)>$ 포천시 $\left(363\right.$ 만 $\left.\mathrm{m}^{3}\right)>$ 용 인시 $\left(355\right.$ 만 $\left.\mathrm{m}^{3}\right)>$ 광주시 $\left(318\right.$ 만 $\left.\mathrm{m}^{3}\right)>$ 청주시 $\left(311\right.$ 만 $\left.\mathrm{m}^{3}\right)>$ 남양 주시 $\left(261\right.$ 만 $\left.\mathrm{m}^{3}\right)>$ 파주시 $\left(249\right.$ 만 $\left.\mathrm{m}^{3}\right)>$ 인천서구 $\left(235\right.$ 만 $\left.\mathrm{m}^{3}\right)>$ 양 주시 $\left(224\right.$ 만 $m^{3}>$ 여주시 $\left(218\right.$ 만 $\left.m^{3}\right)$ 순으로 대부분 수도권에 집중되어 있다. 청주시, 용인시, 여주시 등에서는 선별파 쇄모래를 200 만 $\mathrm{m}^{3}$ 이상을 채취하였으며, 선별파쇄자갈

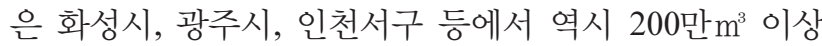
을 채취하였다.

\section{6. 선별세척골재}

선별세척골재는 15 개 시군구에서 채취되었으며, 전국 229 개 시군구의 약 $7 \%$ 를 점유한다(Fig. 1(E)). 선별세척 골재는 주로 바다모래를 세척하는 것으로 대부분 해안을 끼고 있는 시군구에서 세척되는 것이 일반적이다. 경상 남도가 4 개 시군구로 가장 많으며, 전라남도 3 개 시군구, 인천광역시와 경기도가 각각 2 개 시군구, 그리고 부산광 역시, 울산광역시, 충청남도, 제주특별자치도가 1 개 시군 구이다(Table 1). 선별세척골재에서는 자갈보다는 모래의 세척이 활발하여, 모래는 15 개 시군구에서, 자갈은 2 개 시군구에서 세척 생산하였다. Table 3에서 보는 바와 같 이 50 100만 $\mathrm{m}^{3}$ 를 생산한 지역은 1개 시군구이며, 10 50 만 $\mathrm{m}^{3}$ 이 6 개 시군구, $5 \sim 10$ 만 $\mathrm{m}^{3}$ 이 3 개 시군구, $1 \sim 5$ 만 $\mathrm{m}^{3}$ 이 4 개 시군구 등 비교적 적은 양의 골재를 생산한다. 선 별세척골재 채취 상위 시군구(Table 2$)$ 는 창원시 $\left(51\right.$ 만 $\left.^{3}\right)>$ 
서산시 $\left(47\right.$ 만 $\left.m^{3}\right)>$ 부산사하구 $\left(46\right.$ 만 $\left.m^{3}\right)>$ 인천중구 $\left(16\right.$ 만 $\left.m^{3}\right)>$ 울산남구 $\left(14\right.$ 만 $\left.m^{3}\right)>$ 제주시 $\left(11\right.$ 만 $\left.m^{3}\right)$ 순이다.

\section{7. 기타 골재}

2019년에는 신고에 의한 산림골재와 바다골재가 채취 되었다. 산림골재 신고는 강화군, 익산시, 진도군, 정선군 등이며, 바다골재 신고는 해남군과 통영시이다.

\section{4. 권역별 골재개발 현황}

\section{1. 수도권 지역}

수도권 지역은 서울특별시(25구), 인천광역시(8구 2군), 경기도(28시 3군)를 포함한다. 이들 중 서울특별시는 전 체 구에서 골재를 개발한 실적은 전혀 없으며, 인천광역 시의 구 지역에서는 선별파쇄골재만 개발되었고, 강화군 에서는 산림골재신고 물량만 개발되고, 옹진군에는 전국 시군구에서는 유일하게 바다골재가 개발되었다.
인천광역시의 8 개 구 중 4 개 구에서는 선별파쇄, 2 개 구에서는 선별세척골재를 개발하였다(Table 2). 선별파쇄 골재는 서구가 가장 많은 약 235 만 $\mathrm{m}^{3}$ 의 골재를 개발하 였고, 중구, 계양구, 남동구에서는 각각 $40 ~ 50$ 만 $\mathrm{m}^{3}$ 의 골 재를 개발하였다. 선별세척골재는 중구 $\left(16\right.$ 만 $\left.\mathrm{m}^{3}\right)$ 와 서구 $\left(7\right.$ 만 $\left.\mathrm{m}^{3}\right)$ 에서 개발되었다.

경기도의 31 개 시군에서 골재를 개발한 시군은 20 개 시군이며, 11 개 시군에서는 골재의 개발실적은 전혀 없 다(Fig. 1(H)). 골재를 개발이 없는 시군은 대체로 서울특 별시와 인천광역시 사이의 시와 서울특별시와 인접한 시 가 대부분이다. 골재를 개발한 시군들 중 골재허가에 의 해 개발한 시군(Table 2)은 파주시, 포천시, 안성시, 가평 군, 연천군 등 5 개 시군이며, 신고에 의해 개발하는 시군 은 화성시, 포천시, 광주시, 용인시, 남양주시, 여주시 등 20 개 시군이다(Table 2). 모래는 18 개 시군에서 개발되었 으며, 용인시, 포천시, 여주시는 200 만 $\mathrm{m}^{3}$ 이상을, 양주시, 남양주시, 파주시는 100 만 $\mathrm{m}^{3}$ 의 모래를 개발하였다. 자

Table 4. The statistics of aggregate source and local governments

\begin{tabular}{|c|c|c|c|c|c|c|c|c|c|c|c|c|c|c|c|c|}
\hline & Gyeonggi & Gangwon & Chungbuk & Chungnam & Jeonbuk & Jeonnam & Gyeongbuk & Gyeongnam & Jeju & Incheon & Daegu & Busan & Ulsan & Daejeon & Sejong & sum \\
\hline \multicolumn{17}{|l|}{ one type } \\
\hline $\mathrm{R}$ & & 1 & 0 & & & & & & & & & & & & & 1 \\
\hline $\mathrm{L}$ & & 1 & 0 & 1 & & 2 & 3 & & & & & & & & & 7 \\
\hline Mt & & 0 & 1 & 1 & 2 & 6 & 2 & 4 & & & & & & & & 16 \\
\hline M & & 0 & 0 & & & & & & & 1 & & & & & & 1 \\
\hline $\mathrm{C}$ & 13 & 4 & 4 & 3 & 1 & 1 & 1 & 4 & & 2 & 4 & 4 & 1 & 1 & & 43 \\
\hline W & & 0 & 0 & & & 1 & & & & & & & & & & 1 \\
\hline D.(Mt) & & 1 & 0 & & & & & & & 1 & & & & & & 2 \\
\hline \multicolumn{17}{|l|}{ two type } \\
\hline $\mathrm{L}+\mathrm{Mt}$ & & 1 & 0 & 2 & 1 & 3 & 3 & 1 & & & & & & & & 11 \\
\hline $\mathrm{R}+\mathrm{L}$ & & & & & & & 1 & & & & & & & & & 1 \\
\hline $\mathrm{Mt}+\mathrm{C}$ & 5 & 2 & 1 & 2 & 3 & 2 & 4 & 4 & & & & & 1 & & & 24 \\
\hline $\mathrm{L}+\mathrm{C}$ & & 2 & 1 & 2 & & 1 & 2 & & & & & & & & & 8 \\
\hline $\mathrm{Mt}+\mathrm{W}$ & & & & 1 & & 1 & & 1 & & & & & & & & 3 \\
\hline $\mathrm{C}+\mathrm{W}$ & 2 & & & & & 1 & & & & 2 & & 1 & 1 & & & 7 \\
\hline Mt+D.(M) & & & & & & 1 & & & & & & & & & & 1 \\
\hline \multicolumn{17}{|l|}{ three type } \\
\hline $\mathrm{L}+\mathrm{Mt}+\mathrm{C}$ & & 3 & 3 & 1 & 1 & & 4 & & 1 & & & & & & 1 & 14 \\
\hline $\mathrm{Mt}+\mathrm{C}+\mathrm{D} .(\mathrm{M})$ & & & & & 1 & 1 & & & & & & & & & & 2 \\
\hline $\mathrm{R}+\mathrm{Mt}+\mathrm{C}$ & & & & & & & 1 & 1 & & & & & & & & 2 \\
\hline $\mathrm{Mt}+\mathrm{C}+\mathrm{W}$ & & & & & & & & 2 & & & & & & & & 2 \\
\hline $\mathrm{C}+\mathrm{W}+\mathrm{D} .(\mathrm{M})$ & & & & & & & & 1 & & & & & & & & 1 \\
\hline \multicolumn{17}{|l|}{ four type } \\
\hline $\mathrm{L}+\mathrm{Mt}+\mathrm{C}+\mathrm{W}$ & & & & & & & & & 1 & & & & & & & 1 \\
\hline
\end{tabular}


갈은 20 개 시군에서 개발되었는데 200 만m $m^{3}$ 이상의 자갈 은 화성시, 파주시, 광주시, 포천시의 4 개 시군에서, 100 만 $\mathrm{m}^{3}$ 이상의 자갈은 안성시, 연천군, 남양주시, 고양시, 용인시, 김포시 등 6 개 시군에서 개발되었다. 경기도에서 는 육상골재와 하천골재의 개발은 전혀 없다. 산림골재 개발 시군은 연천군, 파주시, 안성시, 포천시, 가평군 등 5 개 시군이며, 선별파쇄 시군은 화성시, 포천시, 용인시, 광주시, 남양주시 등 20 개 시군, 선별세척 시군은 김포시 와 평택시의 2 개 시군이다.

Table 4에서 보는 바와 같이 산림골재와 선별파쇄골재 의 두 종류의 골재를 개발한 시군은 파주시, 포천시, 안 성시, 가평군, 연천군이며, 선별파쇄와 선별세척골재의 두 종류 골재를 개발한 시군은 김포시, 평택시이다. 그 외의 경기도 내의 골재개발 시군은 모두 선별파쇄골재 개발시 군이다.

\section{2. 강원도}

강원도의 18 개 시군에서 골재를 개발한 시군은 15 개 시군이며, 개발실적이 없는 시군은 속초시, 화천군, 양구 군의 3 개 시군이다 $(\mathrm{Fig} .1(\mathrm{H}))$. 골재를 개발한 시군들 중 골재허가에 의해 개발한 시군은 10 개 시군이며(Fig. $1(\mathrm{H}))$, 신고에 의해 개발한 시군은 12 개 시군이다(Table 2). 강 원도에서는 원주시가 200 만 $\mathrm{m}^{3}$ 이상의 골재를 개발하여

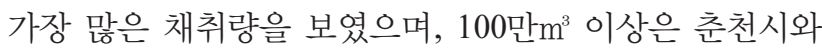
횡성군의 2 개 시군, 나머지 시군들은 그 이하의 채취량 으로 보인다. 모래(Fig. 1(F))는 횡성군, 춘천시, 고성군, 강릉시, 삼척시 등 11 개 시군에서 개발되었으며, 횡성군 만 100 만 $\mathrm{m}^{3}$ 이상의 모래를 개발하였다. 자갈(Fig. $\left.1(\mathrm{G})\right)$ 은 원주시, 춘천시, 영월군, 삼척시, 고성군 등 15 개 시군 에서 개발되었으며 200 만 $\mathrm{m}^{3}$ 이상의 자갈은 원주시에서

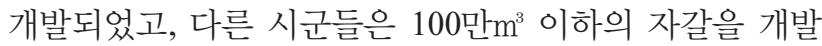
하였다. 골재를 개발한 시군들 중 골재허가에 의해 개발 한 시군(Table 2)은 원주시, 춘천시, 횡성군, 고성군, 강릉 시 등 10 개 시군이며, 신고에 의해 골재를 개발한 시군 (Table 2)은 영월군, 삼척시, 동해시, 원주시, 인제군 등 12 개 시군이다. 하천골재는 평창군의 1 개 군에서만 개발 되었으며, 육상골재는 고성군, 강릉시, 동해시, 원주시 등 7 개 시군에서 개발되었으며, 고성군이 약 81 만 $\mathrm{m}^{3}$ 로 가 장 많이 개발되었다. 고성군 이외의 다른 시군은 10 만 $\mathrm{m}^{3}$ 이하의 소규모 개발만 이루어졌다. 산림골재 개발 시군 은 원주시, 춘천시, 횡성군 등 6 개 시군이며, 선별파쇄 시 군은 영월군, 삼척시, 동해시, 원주시, 인제군 등 12 개 시 군이다. 강원도에서는 선별세척골재를 생산하는 시군은 없다.

골재원별로 개발시군을 분류해보면(Table 4) 하천골재 만 개발한 시군은 평창군 1 개 시군이며, 육상골재만 개
발한 시군은 고성군이며, 선별파쇄골재만 개발한 시군은 영월군, 철원군, 인제군, 태백시이다. 육상골재와 산림골 재의 두 종류 골재를 개발한 시군은 양양군이다. 육상골 재, 산림골재와 선별파쇄골재의 세 종류 골재를 개발한 시군은 원주시, 강릉시, 홍천군이며, 산림골재와 선별파 쇄골재의 두 종류 골재를 개발한 시군은 춘천시와 홍천 군, 육상골재와 선별파쇄골재의 두 종류 골재를 개발한 시군은 동해시, 삼척시이다. 그리고 신고에 의한 산림골 재 개발은 정선군이다.

\section{3. 충청북도}

충청북도의 11 개 시군에서 골재를 개발한 시군은 10 개 시군이며, 개발실적이 없는 시군은 증평군의 1 개 시군이 다(Fig. $1(\mathrm{H})$ ). 청주시가 500 만 $\mathrm{m}^{3}$ 이상의 골재를 개발하 여 충청북도에서는 가장 개발량이 많았으며, 충주시는 200 만 $\mathrm{m}^{3}$ 이상, 진천군은 100 만 $\mathrm{m}^{3}$ 이상의 골재를 개발하 였다(Table 1). 그 외의 8 개 시군은 100 만 $\mathrm{m}^{3}$ 이하의 골 재개발실적을 보인다. 모래(Fig. $1(\mathrm{~F})$ )는 청주시, 진천군, 제천시 등 등 7 개 시군에서 개발되었으며, 청주시만 200 만 $\mathrm{m}^{3}$ 이상의 모래를 개발하였다. 자갈(Fig. $\left.1(\mathrm{G})\right)$ 은 청주 시, 충주시, 진천군 등 9개 시군에서 개발되었으며 200만 $\mathrm{m}^{3}$ 이상의 자갈은 청주시의 1 개 시군에서 개발되었고, 충 주시와 진천군은 100 만 $\mathrm{m}^{3}$ 이하의 자갈을 개발하였다. 골 재허가에 의해 개발한 시군(Table 2)은 충주시, 청주시, 진천군 등 6 개 시군이며, 신고에 의해 골재를 개발한 시 군(Table 2)은 청주시, 음성군, 충주시, 음성군 등 9개 시 군이다. 충청북도에는 하천골재를 개발한 시군은 없다. 육상골재는 충주시, 청주시, 진천군, 옥천군 등 4 개 시군 에서 개발되었으며, 충주시가 약 29 만쪼로 가장 많이 개 발되었다. 산림골재 개발 시군은 청주시, 충주시, 진천군 등 5 개 시군이며, 충주시가 약 175 만 $\mathrm{m}^{3}$ 로 가장 많이 개 발하였다. 선별파쇄 시군은 청주시, 음성군, 제천시, 진천 군 등 9 개 시군으로 청주시가 311 만 $\mathrm{m}^{3}$ 로 가장 많이 개 발하였다. 충청북도에서는 선별세척골재를 생산하는 시 군은 없다.

골재원별로 개발시군을 분류해보면(Table 4) 산림골재 만 개발한 시군은 영동군 1 개 시군이며, 선별파쇄골재만 개발한 시군은 제천시, 괴산군, 음성군, 단양군이며, 육상 골재 + 산림골재 + 선별파쇄 골재를 개발한 시군은 청주시, 충주시, 진천군이다. 산림골재+선별파쇄골재의 두 종류 골재를 개발한 시군은 보은군이며, 육상골재+선별파쇄골 재의 두 종류의 골재를 개발한 시군은 옥천군이다.

\section{4. 대전광역시, 충청남도, 세종특별자치도}

대전광역시의 5 개 구에서 골재를 개발한 구는 선별파 
쇄골재를 개발한 대덕구 한 지역이다. 세종특별자치시는 약 207 만 $\mathrm{m}^{3}$ 의 골재를 개발하였으며, 모래는 76 만 $\mathrm{m}^{3}$, 자 갈은 131 만 $\mathrm{m}^{3}$ 이다. 세종특별자치시에서는 육상골재+산 림골재+선별파쇄골재의 세 종류 골재를 개발하였다. 충 청남도의 15 개 시군에서 골재를 개발한 시군은 13 개 시 군이며, 개발실적이 없는 시군은 논산시, 서천군의 2개 시군이다(Fig. $1(\mathrm{H})$ ). 아산시가 218 만 $\mathrm{m}^{3}$ 의 골재를 개발 하여 충청남도에서는 가장 개발량이 많았으며, 서산시, 홍성군, 예산군은 100 만 $\mathrm{m}^{3}$ 이상의 골재를 개발하였다 (Table 1). 모래(Fig. 1(F))는 공주시, 서산시, 예산군, 아 산시 등 등 11 개 시군에서 개발되었으며, 공주시가 55만 $\mathrm{m}^{3}$ 으로 가장 개발이 활발하였다. 자갈(Fig. $1(\mathrm{G})$ )은 아산 시, 홍성군, 예산군, 서산시 등 11 개 시군에서 개발되었 으며, 아산시가 191 만 $\mathrm{m}^{3}$ 로 가장 개발실적이 많다. 100 만 $\mathrm{m}^{3}$ 이상의 자갈은 아산시, 홍성군에서 개발되었다. 골 재허가에 의해 개발한 시군(Table 2)은 홍성군, 공주시, 서산시, 당진시 등 10 개 시군이며, 신고에 의해 골재를 개발한 시군(Table 2)은 아산시, 예산군, 서산시, 천안시 등 10 개 시군이다. 충청남도에는 하천골재를 개발한 시 군은 없다. 육상골재는 공주시, 청양군, 예산군, 금산군 등 6 개 시군에서 개발되었으며, 공주시가 약 6 만 $m^{3}$ 로 가 장 많이 개발되었다. 산림골재 개발 시군은 홍성군, 공주 시, 서산시, 당진시 등 7 개 시군이며, 홍성군이 약 131만 $\mathrm{m}^{3}$ 로 가장 많이 개발하였다. 선별파쇄 시군은 아산시, 예 산군, 서산시, 금산군 등 9개 시군으로 아산시가 178 만 $\mathrm{m}^{3}$ 로 가장 많이 개발하였다. 선별세척 골재는 서산시의 1 개 시군에서만 생산되었다.

골재원별로 개발시군을 분류해보면(Table 4) 산림골재 만 개발한 시군은 당진시이며, 육상골재만 개발한 시군 은 청양군, 선별파쇄골재만 개발하는 시군은 천안시, 계 룡시, 태안군, 육상골재+산림골재 + 선별파쇄 골재를 개발 한 시군은 홍성군이다. 육상골재+산림골재는 공주시, 보 령시, 육상골재+선별파쇄골재는 금산군, 예산군, 산림골 재+선별파쇄골재는 아산시, 부여군, 산림골재+선별세척 골재는 서산시에서 개발되었다.

\section{5. 전라북도}

전라북도의 14 개 시군에서 골재를 개발한 시군은 9 개 시군이며, 개발실적이 없는 시군은 전주시, 김제시, 진안 군, 무주군, 장수군 등 5 개 시군이다 $(\mathrm{Fig} 1(\mathrm{H}))$. 익산시 $\left(148\right.$ 만 $\left.m^{3}\right)$ 가 전라북도에서는 가장 개발량이 많았으며, 그 외에 100 만 $\mathrm{m}^{3}$ 이상을 개발한 시군은 군산시, 정읍시, 남 원시 등 3 개 시군이다(Table 1). 모래(Fig. 1(F))는 익산시, 고창군, 정읍시, 남원시 등 7 개 시군에서 개발되었으며,
익산시가 55 만 $\mathrm{m}^{3}$ 으로 가장 개발이 활발하였다. 자갈 (Fig. $1(\mathrm{G})$ )은 군산시, 익산시, 정읍시, 남원시 등 9개 시 군에서 개발되었으며, 군산시가 125 만 $\mathrm{m}^{3}$ 로 가장 개발실 적이 많다. 100 만 $m^{3}$ 이상의 자갈은 군산시의 1 개 시군에 서 개발되었다. 골재를 개발한 시군들 중 골재허가에 의 해 개발한 시군(Table 2)은 군산시, 남원시, 정읍시, 고창 군 등 8개 시군이며, 신고에 의해 골재를 개발한 시군 (Table 2)은 익산시, 정읍시, 군산시 등 6 개 시군이다. 전 라북도에는 하천골재, 선별세척골재를 개발한 시군은 없 다. 육상골재는 고창군, 남원시의 2 개 시군에서 개발되었 으며, 고창군이 약 51 만 $\mathrm{m}^{3}$ 로 가장 많이 개발하였다. 산 림골재 개발 시군은 군산시, 남원시, 정읍시, 순창군 등 8 개 시군이며, 군산시가 약 111 만 $\mathrm{m}^{3}$ 로 가장 많이 개발 하였다. 선별파쇄 시군은 익산시, 정읍시, 군산시 등 6 개 시군으로 익산시가 107 만 $\mathrm{m}^{3}$ 로 가장 많이 개발하였다.

골재원별로 개발시군을 분류해보면(Table 4) 한 종류의 골재인 산림골재만 개발한 시군은 순창군, 부안군이며, 선별파쇄골재만 개발하는 시군은 임실군이다. 두 종류의 골재인 육상골재+산림골재를 개발한 시군은 고창군이며, 산림골재+선별파쇄 골재를 개발한 시군은 군산시, 정읍 시, 완주군이다. 세 종류의 골재인 산림골재+산림신고골 재+선별파쇄골재 골재를 개발하는 시군은 익산시이며, 육 상골재 + 산림골재 + 선별파쇄골재의 골재를 개발한 시군은 남원시이다.

\section{6. 광주광역시, 전라남도}

광주광역시는 2019년의 골재개발실적은 없다. 전라남 도의 22 개 시군에서 골재를 개발한 시군은 20 개 시군이 며, 개발실적이 없는 시군은 구례군, 신안군의 2 개 시군 이다(Fig. $1(\mathrm{H})$ ). 나주시가 181 만 $\mathrm{m}^{3}$ 의 골재를 개발하여 전라남도에서는 가장 개발량이 많았으며, 그 외에 100 만 $\mathrm{m}^{3}$ 이상을 개발한 시군은 해남군, 화순군의 2 개 시군이 다(Table 3). 모래(Fig. 1(F))는 함평군, 영암군, 영광군, 곡 성군 등 12 개 시군에서 개발되었으며, 함평군이 19 만 $\mathrm{m}^{3}$ 으로 가장 개발이 활발하였다. 그러나 전라남도의 시군 에서 모래 개발량은 20 만 $\mathrm{m}^{3}$ 이하로 매우 적은 편이다. 모래의 개발량은 자갈의 개발량에 비해 $10 \%$ 수준으로 매우 낮다. 자갈(Fig. $1(\mathrm{G})$ )은 나주시, 화순군, 해남군, 장 성군 등 14 개 시군에서 개발되었으며, 나주시가 181 만m ${ }^{3}$ 로 가장 개발실적이 높다. 그 외에 100 만m $\mathrm{m}^{3}$ 이상의 자갈 은 화순군과 해남군의 2 개 시군에서 개발되었다. 골재허 가에 의한 골재개발 시군(Table 2)은 나주시, 화순군, 해 남군, 장성군 등 16 개 시군이며, 신고에 의해 골재를 개 발한 시군(Table 2)은 광양시, 순천시, 해남군, 진도군 등 
10 개 시군이다. 전라남도에는 하천골재를 개발한 시군은 없다. 육상골재는 화순군과 함평군 등 6 개 시군에서 개 발되었으며, 함평군이 약 19 만 $\mathrm{m}^{3}$ 로 가장 많이 개발하였 다. 산림골재 개발 시군은 나주시, 해남군, 화순군, 장성 군 등 13 개 시군이며, 나주시가 약 181 만 $\mathrm{m}^{3}$ 로 가장 많 이 개발하였다. 선별파쇄골재 개발 시군은 광양시, 순천

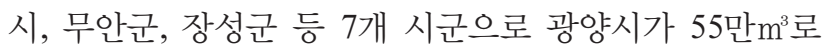
가장 많이 개발하였다. 선별세척골재 개발 시군은 고흥 군, 보성군, 광양시의 3 개 시군이며, 개발량은 각각 6 만 $m^{3}$ 이하로 매우 적은 편이다.

골재원별로 개발시군을 분류해보면(Table 4) 한 종류의 골재인 선별파쇄골재만 개발한 시군은 목포시, 선별세척 골재만 개발한 시군은 보성군, 산림골재만 개발한 시군 은 담양군, 곡성군, 강진군, 여수시, 나주시, 완도군. 또한 육상골재만 개발한 시군은 장흥군, 영암군이다. 두 종류 의 골재인 육상골재+산림골재를 개발한 시군은 화순군, 함평군, 영광군, 산림골재+선별파쇄를 개발한 시군은 순 천시, 장성군, 산림골재+바다신고골재를 개발하는 시군 은 해남군, 육상골재+선별파쇄골재를 개발한 시군은 무 안군, 그리고 산림골재+선별세척골재를 개발한 시군은 고 흥군, 선별파쇄골재+선별세척골재를 개발한 시군은 광양 시이다. 또한 세 종류의 골재인 산림골재 + 산림신고골재 +선별파쇄골재를 개발한 시군은 진도군이다.

\section{7. 대구광역시, 경상북도}

대구광역시의 8 개 구군에서 골재를 개발한 구군은 동 구, 북구, 달서구, 달성군의 4 개 구군이다 $($ Fig. $1(\mathrm{H}))$. 이 들은 모두 선별파쇄골재를 개발하였으며, 구군별로 개발 량은 적으나 달성군이 약 24 만 $\mathrm{m}^{3}$ 로 가장 많이 개발하였 다. 경상북도의 23 개 시군에서 골재를 개발한 시군은 21 개 시군이며, 개발실적이 없는 시군은 영양군과 울릉군 의 2 개 시군이다(Fig. $1(\mathrm{H}))$. 안동시가 유일하게 100 만 $^{3}$ 이상인 134 만 $\mathrm{m}^{3}$ 의 골재를 개발하여 경상북도에서는 가 장 개발량이 많았다. 모래(Fig. $1(\mathrm{~F})$ )는 안동시, 경산시, 영덕군, 울진군 등 18 개 시군에서 개발되었으며, 경산시 가 42 만m $\mathrm{m}^{3}$ 으로 가장 개발이 활발하였다. 자갈 $($ Fig. $1(\mathrm{G}))$ 은 안동시, 고령군, 구미시, 군위군 등 17 개 시군에서 개 발되었으며, 안동시가 92 만 $\mathrm{m}^{3}$ 로 가장 개발실적이 높다. 골재허가에 의해 골재를 개발한 시군은 영덕군, 안동시, 김천시, 군위군 등 20 개 시군이며, 신고에 의해 골재를 개발한 시군은 안동시, 경산시, 칠곡군, 고령군 등 11 개 시군이다(Table 2). 하천골재는 구미시와 의성군의 2 개 시 군에서만 개발되었는데, 개발량은 구미시 32 만 $\mathrm{m}^{3}$, 의성 군 8 만 $\mathrm{m}^{3}$ 이다. 육상골재는 의성군, 김천시, 안동시, 예천
군 등 13 개 시군에서 개발되었으며, 의성군이 약 26 만m 로 가장 많이 개발하였다. 산림골재 개발 시군은 영덕군, 고령군, 김천시, 안동시 등 14 개 시군이며, 영덕군이 약 75 만 $\mathrm{m}^{3}$ 로 가장 많이 개발하였다. 선별파쇄골재 개발 시 군은 안동시, 경산시, 칠곡군, 고령군 등 11 개 시군으로 안동시가 71 만 $\mathrm{m}^{3}$ 로 가장 많이 개발하였다. 경상북도에 서는 선별세척골재를 개발한 시군은 없다.

골재원별로 개발시군을 분류해보면(Table 4) 한 종류의 골재인 육상골재만 개발한 시군은 포항시, 상주시, 예천 군, 산림골재만 개발한 시군은 문경시, 영천시, 선별파쇄 골재만 개발한 시군은 청송군이다. 두 종류의 골재인 육 상골재+산림골재를 개발한 시군은 김천시, 영덕군, 울진 군, 육상골재+하천골재를 개발한 시군은 의성군, 육상골 재 + 선별파쇄골재를 개발한 시군은 경주시, 봉화군, 산림 골재+선별파쇄골재를 개발하는 시군은 경산시, 청도군, 고령군, 칠곡군이다. 그리고 세 종류의 골재인 육상골재 + 산림골재 + 선별파쇄골재를 개발한 시군은 안동시, 영주 시, 군위군, 성주군, 하천골재 + 산림골재 + 선별파쇄골재를 개발한 시군은 구미시이다.

\section{8. 부산광역시, 울산광역시, 경상남도}

부산광역시의 16 개 구군들 중에서 영도구, 강서구, 사 상구, 사하구, 기장군의 5 개 구군에서 골재를 개발하였다 (Fig. $1(\mathrm{H}))$. 이들 중 사하구는 약 137 만 $\mathrm{m}^{3}$ 로 골재 개발 량이 가장 많다. 영도구, 강서구, 사상구, 기장군은 선별 파쇄골재만 개발하였고, 사하구는 선별파쇄골재와 선별 세척골재의 두 종류 골재를 개발하였다.

울산광역시의 5 개 구군들 중에서 남구, 북구, 울주군의 3 개 구군에서 골재를 개발하였다(Fig. $1(\mathrm{H}))$. 울주군이 약 792 만 $\mathrm{m}^{3}$ 로 전국 시군들 중 가장 많은 골재를 개발하였 다. 선별파쇄골재만 개발한 구군은 북구의 1 개 구이며, 남구는 선별파쇄골재 + 선별세척골재의 두 종류 골재를 울 주군은 산림골재+선별파쇄골재의 두 종류 골재를 개발하 였다.

경상남도의 18 개 시군 모두에서 골재를 개발하였다 (Fig. $1(\mathrm{H}))$. 김해시가 328 만 $\mathrm{m}^{3}$ 의 골재를 개발하여 경상 남도에서는 가장 개발량이 많았으며, 그 외에 100 만 $\mathrm{m}^{3}$ 이상의 골재 개발한 시군은 창원시, 양산시, 의령군, 함 안군의 4 개 시군이다. 모래(Fig. $1(\mathrm{~F})$ )는 김해시, 의령군, 함안군, 창원시 등 12 개 시군에서 개발되었으며, 김해시

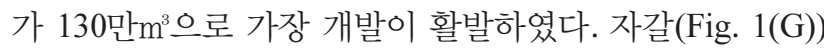
은 김해시, 양산시, 밀양시, 산청군 등 18 개 시군에서 개 발되었으며, 김해시가 199 만 $\mathrm{m}^{3}$ 로 가장 개발실적이 높다. 허가에 의해 골재를 개발한 시군은 김해시, 의령군, 함안 
군, 거창군 등 13 개 시군이며, 신고에 의해 골재를 개발 한 시군은 양산시, 밀양시, 창원시, 하동군 등 13 개 시군 이다(Table 2). 하천골재는 의령군(약 56 만 $\mathrm{m}^{3}$ )에서만, 육 상골재는 함안군 $\left(1.4\right.$ 만 $\left.\mathrm{m}^{3}\right)$ 에서만 개발되었다. 산림골재 개발 시군은 김해시, 함안군, 거창군, 산청군 등 13 개 시 군이며, 김해시가 약 301 만 $\mathrm{m}^{3}$ 로 가장 많이 개발하였다. 선별파쇄골재 개발 시군은 양산시, 밀양시, 하동군, 창원 시 등 12 개 시군으로 양산시가 약 119 만 $m^{3}$ 로 가장 많이 개발하였다. 선별세척골재 개발 시군은 창원시, 통영시 등 4 개 시군이며, 창원시가 약 51 만 $\mathrm{m}^{3}$ 로 가장 많은 채 취량을 보인다.

골재원별로 개발시군을 분류해보면(Table 4) 한 종류의 골재인 산림골재만 개발한 시군은 산청군, 함양군, 거창 군, 합천군, 선별파쇄골재만 개발한 시군은 밀양시, 고성 군, 남해군, 하동군이다. 두 종류의 골재인 육상골재+산 림골재를 개발한 시군은 함안군, 산림골재+선별파쇄골재 를 개발한 시군은 김해시, 양산시, 창녕군, 진주시, 산림 골재+선별세척골재를 개발한 시군은 거제시이다. 세 종 류의 골재인 산림골재+선별파쇄골재+선별세척골재를 개 발한 시군은 창원시와 사천시, 하천골재 + 산림골재 + 선별 파쇄골재를 개발한 시군은 의령군, 바다신고골재 + 선별파 쇄골재 + 선별세척골재를 개발하는 시군은 통영시이다.

\section{9. 제주특별자치도}

제주특별자치도는 제주시의 골재개발량 $\left(\right.$ 약 84 만 $\left.\mathrm{m}^{3}\right)$ 이 서귀포시(약 58만 $\left.\mathrm{m}^{3}\right)$ 보다 많은 편이다(Fig. 1(H)). 제주 시는 육상골재 + 산림골재 + 선별파쇄골재 + 선별세척골재의 네 종류 골재를 개발하였으며, 서귀포시는 육상골재+산 림골재+선별파쇄골재의 세 종류 골재를 개발하였다(Table 4).

\section{5. 토 의}

전국 229개 시군구에서 2019년에 골재를 개발한 시군 구는 148 개 시군구로 전체 시군구의 약 $65 \%$ 에 달한다 (Fig. 1(H)). 7대 광역시(74 시군구)에서는 19개 시군구에 서 골재를 개발하였으며, 이들을 제외한 도 지역의 155 개 시군 중 $83 \%$ 인 129 개 시군에서 골재개발이 이루어졌 다. 광역시를 제외하고는 우리나라의 대부분 시군에서 골 재를 개발하고 있다고 볼 수 있다.

골재원별로 보았을 때 선별파쇄골재를 개발하는 시군 구는 105 시군구, 산림골재는 75 개 시군구, 육상골재는 42 개 시군구, 선별세척은 15 개 시군구, 하천골재는 4 개 시군구, 바다골재는 1 개 군, 그리고 신고에 의한 산림과 바다골재 개발이 6개 시군구이다. 따라서 우리나라 시군 구에서의 골재개발은 선별파쇄골재가 주도하고 있으며,
산림골재가 그 뒤를 따르고 있다. 실제로 2019년의 골재 총 생산의 $90 \%$ 이상을 두 골재원에서 개발되었다.

국내에서 100 만 $\mathrm{m}^{3}$ 이상의 골재를 개발하는 시군구는 골재채취시군구의 약 $28 \%$ 인 41 개 시군구이지만 이들이 개발한 골재는 전체 골재 생산량의 약 $70 \%$ 인 약 9,340 만 $\mathrm{m}^{3}$ 이다. 이는 골재는 모든 시군구에서 반드시 필요한 건설자재이지만 실제 골재 개발은 특정 시군구에 편중되 어 있어 골재 수급의 불균형을 초래하는 원인이 되기도 한다. 또한 수도권에 약 $38 \%$ 인 14 개 시군구가 집중되어 있다.

2019년에 골재를 가장 많이 채취한 지역은 울주군이며, 그 다음으로 화성시, 청주시, 포천시, 파주시 등으로 모 두 400 만m ${ }^{3}$ 이상의 골재를 채취하였다. 산림골재는 울주 군에서의 채취량이 가장 많았으며, 선별파쇄골재는 화성 시, 육상골재는 강원도 고성군, 선별세척골재는 창원시에 서 가장 많은 채취량을 보였다. 모래를 가장 많이 채취 한 지역은 청주시이며, 자갈은 울주군에서의 채취가 가 장 많았다.

Fig. 2 는 시군구의 골재 채취량과 채취시군구의 수를 비교한 그림이다. 이 그림에서 보듯이 500 만 $\mathrm{m}^{3}$ 이상의 골재채취는 3 개 시군구, 400 500만 $\mathrm{m}^{3}$ 이상은 2 개 시군 구 등 100 만 $\mathrm{m}^{3}$ 이상의 골재채취시군은 42 개 시군구이다. 이들 100 만 $\mathrm{m}^{3}$ 이상의 골재 채취 시군구는 대부분 광역 시 주변의 시군으로 광역시 내의 골재수급을 주목적으로 한다. 100 만 $\mathrm{m}^{3}$ 이상 채취 시군구들 중 약 $30 \%$ 가 수도권 에 집중되어 있으며, 나머지 시군구는 대구광역시를 제 외한 광역시의 주변에 집중되어 있는 것이 특징이다. 연 간 약 $10 \sim 50$ 만 $\mathrm{m}^{3}$ 의 골재를 채취하는 시군구는 50 개 시 군구로 가장 많지만 실제로 골재의 생산성은 그다지 높 은 편은 아니다. 그러나 이러한 시군구들은 자체 조달 또 는 주변의 한두 시군구로의 반출 등 지역적인 규모에서 는 자체 수급이 가능하다. Fig. 3은 골재의 채취규모와 골재원별 채취시군을 비교한 그림이다. 이 그림에서 보 듯이 선별파쇄와 산림골재의 채취시군이 채취규모와 관 계없이 대다수를 점하고 있는 것을 볼 수 있다. 10 50만

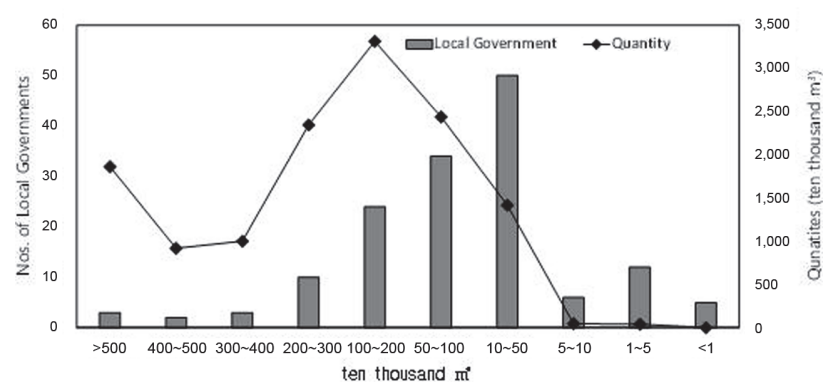

Fig. 2. The quantities of aggregates by local governments. 


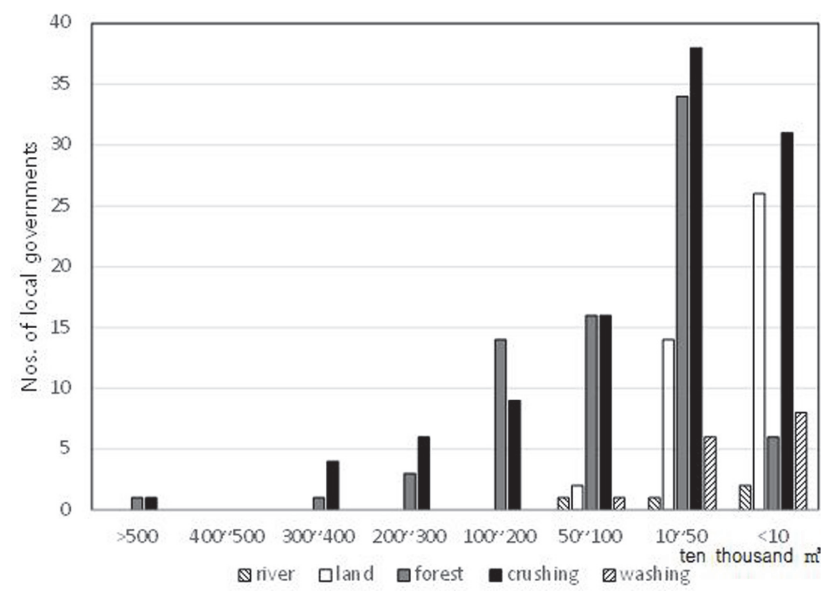

Fig. 3. The quantities by aggregate sources by local governments.

$\mathrm{m}^{3}$ 의 채취규모를 보이는 시군구들에서의 골재원은 대부 분 선별파쇄와 산림골재임을 알 수 있으며, 또한 골재종 류별, 허가/신고별로 보아도 $10 \sim 50$ 만 $\mathrm{m}^{3}$ 을 채취하는 시 군구가 가장 많음을 알 수 있다. 육상골재만 $10 \sim 50$ 만 $\mathrm{m}^{3}$ 과 10 만 $\mathrm{m}^{3}$ 이하의 골재를 채취하는 시군구가 많다.

Fig. 4는 광역시도별로 골재를 채취하는 시군구 수와 채취된 골재 생산량을 비교한 그림이다. 이 그림에서 보 면 경기도, 경상남도, 경상북도, 전라남도는 골재채취시 군수는 비슷하지만 채취량은 큰 차이를 나타낸다. 경기 도가 시군구별 평균채취량이 가장 많다. 충청북도와 울 산광역시는 골재채취시군구는 적지만 채취량은 상대적으 로 높음을 알 수 있다. 채취시군구와 골재채취량의 비교 에서 알 수 있듯이 채취시군구가 많다고 채취량이 많은 것은 아니다. 한 시군구에서도 골재의 채취량이 많을 수 있는데, 그 예로 울주군을 들 수 있다. 울주군은 전국 골 재채취량 1 위인 지역으로 2019년도 골재채취량의 $5.9 \%$ 를 점유하였으며, 울주군을 비롯하여 화성시, 청주시의 3 개 시군에서 채취된 골재는 국내 골재 채취량의 $14 \%$ 를 차지하였다.

국내에서의 골재 분류는 골재원을 기준으로 하고 있으 며, 이를 허가와 신고의 두 타입으로 구분하여 골재채취 법에서 관리하고 있다. 따라서 이들 기준에 따라 골재는 하천, 육상, 바다, 산림골재로 구분하고 이들의 골재 채 취가 허가와 신고에 의해 채취할 수 있도록 하였으며, 선 별파쇄와 선별세척의 골재는 신고에 의해서만 골재채취 가 가능하다. 따라서 국내 골재는 총 10 종류로 분류된 다. 2019년에 한 시군구에서 최대 네 종류의 골재를 채 취하였는데, Table 4에서 보듯이 한 종류의 골재는 71 개 시군구에서, 두 종류의 골재는 55 개 시군구에서, 세 종류 의 골재는 21 개 시군구에서, 그리고 4 종류의 골재는 1

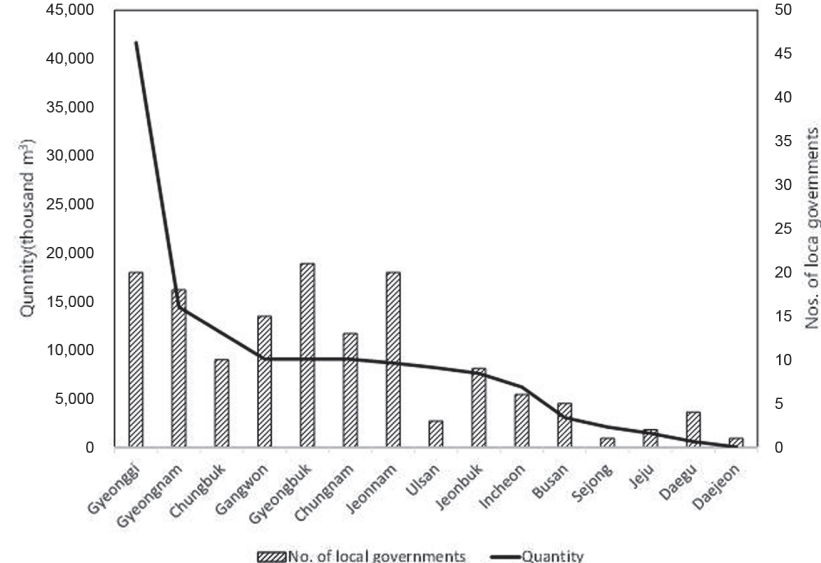

Fig. 4. The comparison of number of local governments and aggregate volume produced by regional government.

개 시군구에서 채취되었다. 한 종류의 골재에서는 선별 파쇄골재, 두 종류의 골재에서는 산림골재 + 선별파쇄골재, 세 종류의 골재에서는 육상골재 + 산림골재 + 선별파쇄골재 의 타입이 가장 많았다.

모래와 자갈을 모두 채취한 시군구는 92 개 시군구이며, 모래만 채취한 시군구는 17 개 시군구, 자갈만 채취한 시 군구는 39 개 시군구이다. 또한 허가+신고에 의해서 골재 를 채취한 시군구는 57 개 시군구, 허가에 의해서만 골재 를 채취한 시군구는 36 개, 신고에 의해서만 골재를 채취 한 시군구는 55 개 시군구이다.

\section{6. 결 론}

1. 2019 년에는 전국 229 개 시군구들 중 약 $65 \%$ 인 148 개 시군구에서 골재를 채취하였다.

2. 모래만 채취한 시군구는 17 개 시군구, 자갈만 채취 한 시군구는 39 개 시군구, 그리고 모래와 자갈을 모두 채 취한 시군구는 92 개 시군구이다. 선별파쇄골재는 105 개 시군구, 산림골재는 42 개 시군구, 육상골재는 42 개 시군 구, 선별세척골재는 15 개 시군구, 하천골재는 4 개 시군구, 바다골재는 1 개 시군구, 산림 및 바다골재신고는 4 개 시 군에서 채취되었다.

3. 시도별로 보았을 때 경상북도는 21 개 시군구, 경기 도와 전라남도는 20 개 시군구, 경상남도는 18 개 시군구, 강원도는 15 개 시군구, 충청남도는 13 개 시군구, 충청북 도는 10 개 시군구, 전라북도는 9 개 시군구, 제주특별자치 도는 2 개 시에서 골재를 채취하였으며, 인천광역시는 6 개 구군, 부산광역시는 5 개 구군, 울산광역시는 3 개 구군 에서 골재를 채취하였다. 광역시를 제외한 도 지역의 시 
군 $80 \%$ 이상에서 골재가 채취되었다.

4. 2019 년에 500 만 $\mathrm{m}^{3}$ 이상의 골재를 채취한 3 개 시군 구를 포함하여, 100 만 $\mathrm{m}^{3}$ 이상의 골재를 채취한 시군구는 42개 시군이며, 채취된 골재물량은 약 9,340만 $\mathrm{m}^{3}$ 로 2019 년 골재채취물량의 약 $70 \%$ 에 달한다. 골재를 채취하는 시군에서의 골재 채취가 대형화되었음을 의미한다. 또한 $50 \sim 100$ 만 $\mathrm{m}^{3}$ 의 골재는 34 개 시군구에서, $10 \sim 50$ 만 $\mathrm{m}^{3}$ 골 재는 50 개 시군구에서 채취되어 국내 골재채취시군의 $57 \%$ 를 차지하지만 실제 골재채취량은 3,860 만 $\mathrm{m}^{3}$ 로 전 체 채취량의 $29 \%$ 에 불과하다. 이는 각 지역에서 필요한 골재를 자체 조달하는 정도의 수요공급을 맞추어 채취하 고 있음을 보여준다.

5. 2019년도에는 하천골재신고, 육상골재신고를 제외한 모든 형태의 골재채취방법을 통해 골재를 채취하며, 또 한 다양한 골재채취방법을 통해 각 지역의 골재를 개발 하여 수급하고 있다. 따라서 시군구에서의 골재채취패턴 은 매우 다양하며, 각각의 지역마다 필요한 형태로 골재 를 조달하고 있음을 나타낸다.

\section{사 사}

이 연구는 한국지질자원연구원에서 수행하고 있는 국 토교통부 “2021년 골재자원조사 및 관리사업(IP2021-006)" 의 지원으로 수행되었습니다. 또한 논문에 대한 세심한 검토와 제안을 해주신 심사위원 분들게 감사드립니다.

\section{References}

Hong, S.S. and Lee, J.Y. (2020) Analysis of 2019 domestic aggregate production in Korea(I), Korea Econ. Environ. Geol., v.53, p.755-769.

Hong, S.S., Kim, J.Y., and Lee, J.Y. (2015) Trends of supply and demand of aggregate in Korea(I), Jour. Petro. Soc. Korea, v.24, p.253-272. doi: 10.7854/JPSK.2015.24.3.253

Ministry of Land, Infrastructure and Transport, 2019, Annual aggregate statistics, www.agris.go.kr

Ministry of Land, Infrastructure and Transport, 2014, The $5^{\text {th }}$ Basic plan for supply and demand of aggregate, $358 \mathrm{p}$.

Ministry of Land, Infrastructure and Transport, 2018, The $6^{\text {th }}$ Basic plan for supply and demand of aggregate, 368p. 